\title{
Loodus tuleb tagasi: delfiinid ja saurused. Libauudistest, photoshop-muistenditest ja meemidest koroonakarantiini ajal
}

\author{
Eda Kalmre \\ Eesti Kirjandusmuuseumi folkloristika osakonna vanemteadur \\ eda.kalmre@folklore.ee
}

\begin{abstract}
Teesid: Artiklis jälgitakse koroonakarantiini esimestel kuudel sotsiaalmeedia postitustest ja libauudistest tõuke saanud jutusuunda, kuidas justkui karantiinist tingitud saaste vähenemine mõjub keskkonnale positiivselt ja loodus taastub. Avatakse teema konteksti ja jälgitakse retoorika muutumist läbi erinevate žanride kultuuriliste maatriksite. Arutletakse selle üle, kuivõrd on pildil võime jutustada tõepärast lugu. Missugune on sel juhul konteksti, tõe ja retoorika suhe?

Märksõnad: kuulujutt, libauudis, meem, osaluskultuur, paroodia, sotsiaalmeedia, tänapäeva muistend e linnamuistend, valetamisnaljand
\end{abstract}

Folkloristil on 2020. aasta esimestest kuudest alanud üleilmse kriisi rahvalikud vastukajad väga huvitavad jälgida, sest suur osa sellest, mille abil inimesed sotsiaalmeedias praegust globaalset hädaolukorda kõigis selle tahkudes lahkavad, põhineb folklooril, s.t uskumustel, linnamuistenditel, kuulujuttudel, naljadel, narratiividel, mis omakorda tuginevad suuresti kultuuris varem käigus olnud motiividele, mudelitele ja struktuuridele. Folkloristid kogu maailmas on seda materjali ka iseseisvalt ja ühiste projektide käigus kogunud (vt Kõiva \& Voolaid 2020). ${ }^{1}$ Värske ülevaate esimeste kuude pandeemiafolkloorist on andnud eesti folkloristide ühisartikkel (vt Hiiemäe \& Kalda et al. 2020). Järgnevalt siin tutvustatavad näited meemidest on kogutud artikli autori ligemale 400 Facebooki sõbra postituste hulgast ning Facebooki gruppide The Belief Narrative Network (BNN) ning International Society for Contemporary Legend Research postituste seast. 


\section{Pilt ja sõna. Sarnased fenomenid ja nende kirjeldamise kultuurilised vormid}

Üks koroonaaja suhtluse märgiline nähtus on jagatavad piltide ja tekstidega sõnumid - meemid. Nende vahendusel toimiv osaluskultuur on tihtilugu väga intensiivne ja globaalne. Kuigi meemikommunikatsioon on juba aastaid olnud sotsiaalmeedias aina populaarsem, on ülemaailmne pandeemiaaeg, mil inimsuhtlus ongi kandunud suures mahus internetti, muutnud selle tõeliselt vohavaks. Ajakirjanik Esta Tatrik on tõdenud üleilmse pandeemia alguses Postimehes, et tänu koroonakriisi alguses sotsiaalmeedia üle ujutanud meemidele on meil kahtlemata käsil üks vaimukamaid ja naljakamaid maailmalõppe (Tatrik 2020). Tõesti, provisoorselt on tänapäeva meemivorm ${ }^{2}$ vaieldamatult kõige nähtavam ja ilmekam selles sotsiaalmeedia koroonateemaatika osaluskultuurses kommunikatsioonis. Laias laastus tähendab see visuaalses vormis teabe edastamist netis; seal hõlpsasti levivate ideede ja kujundite miksimist. Huumor, korduvus, dialoogilisus, lihtsus, loomingulisus, mängulisus, pildilisus, ettearvamatus ja digitaalne kontekst - kõik need märksõnad iseloomustavad meeme (Shiftman 2007; $2011 \mathrm{jm}$ ). Tõesti, naljategemine on neis meemides enamasti esikohal, huumor annab sõnumile (ka murelikule ja kahtlusi-kõhklusi edasi andvale sõnumile) pehmendava ning üldistava jõu.

Suurem osa tänapäeval rahvalikus vormingus ja stiilis ringlevast materjalist on vastukaja mingile reaalelu sündmusele ja seda kajastavale/tõlgendavale uudisloole. Folkloristid on kokku leppinud, et kogu seda materjali võiks käsitleda uudisfolkloorina (ingl newslore vrd folk-loor). Tegelikult võivad rahvalikud vastukajad hõlmata mitte üksnes meeme, vaid paljusid muidki vorme: laulu-, filmi- jms paroodiaid, nalju, linnamuistendeid, animeeritud joonisfilme, digitaalselt töödeldud fotosid jms. Kogu seda materjali võib vaadelda ka uudistest lähtuva omamoodi rahvaliku meediakriitikana (vt Frank 2011: 7, 166 jj).

Meemid ja nende tõlgendamine pakuvad tänapäeval huvi sotsiaalpsühholoogidele, kommunikatsiooni, popkultuuri ja huumori uurijatele samavõrra kui folkloristidele. Tänapäeva muistendite (rahvapärases kõnepruugis linnalegendide) uurijad on juba peaaegu paarkümmend aastat tegelenud ainesega, kus algselt pakutakse pildina justkui tõest materjali. Üks esimesi, kes sellest kirjutas, oli Russell Frank (2003). Tema nimetas selliseid fotodel põhinevaid jutustusi fotograafilisteks ehk fotoshopitud linnamuistenditeks (photoshop urban legend). Väga palju mõjutasid selle pildilise materjali esilekerkimist suured katastroofid, näiteks WTC terrorirünnak, orkaan Katrina New Orleansis jt. Mäletan üht Rahvusvahelise Tänapäeva Muistendite Uurijate Seltsi konverentsi Dublinis 2007, kus ameerika folklorist Diane Goldstein rääkis oma ettekande väliselt internetis ringlevatest mingile erakordsele või kurioossele seigale vii- 
tavatest justkui originaalsetest fotodest kui uuenenud žanrist, visuaalsetest narratiividest. Tookord tõdeti selles rahvusvahelises kvoorumis ühiselt, et pilt jutustab lugu, pildis/fotos on olemuslikult tõe retoorika, sest fotograaf on justkui jäädvustanud reaalse hetke ja see, mida oma silmaga nähakse, on usutav ning paljud niisugused pildijutustused kasutavad usundis, rahvajuttudes s.o kultuuris üldteada olevaid motiive. ${ }^{3}$ Ka Russell Frank pakub oma artiklis välja kolm põhilist kriteeriumi, mille alusel võib väita, et tegemist on foto kujul esitatud linnamuistendiga: 1 . pilt peab jutustama lugu, 2. see peab olema erakordne, mõjuma usutavalt, aga olema vale, 3. ta peaks vähemalt kaudselt väljendama ohtu/ohuolukorda meile, meie tervisele ja psüühilisele tasakaalule. Frank toob oma esmases käesoleva teemaga tegelevas artiklis välja kaks n-ö tehnilist fenomeni, kuidas niisugune lugu üles ehitatakse. See pildilugu võib olla loodud kasutades õiget (tõest) fotot või põhineda nn petufotol (töödeldud fotol). Frank kasutab seda nähtust sisuliselt iseloomustades vanema jututraditsiooni kaudu žanrimääratlust - valetamisnaljand - valetamisnaljand-foto (tall-tale photograph) (Frank 2003: 120). ${ }^{4}$

Nii nagu muistendite ja libauudiste puhul mängib olulist rolli näiline ja raskesti kontrollitav tõepära, on ka digitaalses meedias fotosid kasutavate meemide puhul üks kriteeriume tõesuse loomine läbi sideme reaalsusega. Limor Shifman on uurinud fotosid kasutavate meemide jagatud ja korduvatel mustritel põhinevaid loomisprotsesse ning väidab, et "fotopõhised meemid toimivad hüpertähendusliku režiimina, kus kood ise saab tähelepanu keskpunkti ja toimib fotograafiana, kus fotosid tajutakse üha enam tulevaste piltide toorainena. Lõpuks nende kahe raami ühendamisega kontseptualiseeritakse meemid kui operatiivmärgid - tekstikategooriad, mis on kavandatud kutseteks (loovale) tegevusele. Kuigi need omadused ilmnesid ühel või teisel viisil ka fotograafia traditsioonilistes vormides, on nad kujunenud valitsevaks loogikaks ajastul, mida iseloomustab digitaalse fotograafia ja osaluskultuuri liitmine" (Shifman 2014).

Meemide sõnum ei ole läbivalt ainuüksi kerge ja naljaline. Paljutki sellest on võimalik vaadelda läbi uskumusliku ja muistendiuurimusliku vaate ehk siis muistenditele nii iseloomuliku liikuva (mitte fikseeritud) tõe ja reaalsuse skaala (Bennett 1988: 32-33 jt; Ellis 2018: 400 jt). Asjaolu, et tõde jaguneb erinevatesse kategooriatesse, sõltudes sellest, kas ja kuidas me suudame demonstreerida, kas see on objektiivselt tõde või vale. See liikuv-liminaalne tõeskaala, kus puuduvad turvalised standardid, ongi muistendeid ning nende sisu lühemas vormis vahendavaid kuulujutte käigus hoidev tegur. Aga isegi ümberlükatud linnamuistendid sisaldavad elemente, mis ometi peegeldavad osi tänapäeva realiteedist ja selle muutumisest (Ellis 2018: 401). 
Üks fototöötlusega meemi mitmetise oleku (libiseva tõeskaala) esinduslikumaid näiteid on "Turist" (ka WTC gay või "Pahaaimamatu turist"). Sellele New Yorgi maailmakaubanduskeskuse tipus tehtud fotole on jäädvustunud hetk enne torni rammimist. Foto olevat ilmutatud negatiivist, mis olevat leitud WTC rusudest ning see näitavat selgesti, kuidas esimene lennuk sõitis torni sisse. Pildile on jäänud ka rõõmsalt poseeriv turist, kellel pole oma kurvast saatusest veel aimugi. Foto New Yorgi kaksiktorni katusel 11. septembri hommikul poseerivast pahaaimamatust turistist, taamal paistmas otse torni suunas lendav lennuk, kajastas justkui erakordset olukorda ja mõjus esimesel pilgul ka üsna usutavalt, algselt see netis ilmselt mõni aeg niisuguse sõnumiga ringleski. See kena lugu osutus siiski valeks. Varsti järgnes debatt selle loo üle ning veebiskeptikud ja -analüütikud tegid selgeks, et foto näitab vaid autori nigelaid oskusi professionaalidele mõeldud pilditöötlusprogrammis Adobe PhotoShop. Kõnealusel fotol tuleb lennumasin põhjast ning seetõttu peaks olema tegemist lõunatorniga. Seal aga polnud vaateplatvormi ja kui isegi oleks olnud, oleks see avatud alles kell 9.30. Lennukid rammisid torne aga kella üheksa paiku. Eksperdid on välja selgitanud, et fotol on näha Boeing 757, mitte Boeing 767, mis tegelikult torni rammis. 11. septembri hommik oli päikseline, mistõttu jääb arusaamatuks, miks turist on nii soojalt riietunud. Tegelikult on lugu selline, et pildil olev Peteri-nimeline ungarlane tegi ise fotomontaaži, ning see oli mõeldud vaid sõpradele näitamiseks, aga nagu internetis kombeks, levib kõik välgukiirusel. Ehtsad fotod olid tehtud 28. novembril 1997 (vt Frank 2003; Shifman 2014). Selle foto edasine populaarsus meenutas väga hiljutist 2021. aasta USA presidendi ametisse vannutamise publiku hulgas istunud Bernie Sandersi kuju viraalseks muutumist. Selle vahega, et kui Bernie Sandersi kössitav veidi absurdsena mõjuv suurte kinnastega kuju oli justkui kohalolu iseenesest ning sobitus kergesti ükskõik missugusesse konteksti, siis turisti kuju muutus netis populaarseks, aga säilitas paljuski algse pahaaimamatuse idee: teda lisati neile fotodele, kus hakkas midagi juhtuma: pahaaimamatu turisti võib leida rannast kui sellele läheneb hiidlaine, Kennedy autost enne mõrva, enne dirižaabli õnnetust jm sarnastest erilistest kohtadest.

Üks rahvajutu (muistendi või valetamisnaljandi) ajaloolisele maatriksile lähedane tänapäevase meedia kommunikatsiooni vorm on liba- e valeuudis. Selle sisu ja eesmärk võib olla väga erinev: poliitilist ebastabiilsust tekitav, mingit uskumust (nt vandenõuteooriat) edastav, kõmuline, meelelahutuslik vms. Mitmed definitsioonid rõhutavad seda, et libauudis ehk valeuudis (ingl fake news) on desinformeeriv, tahtlikult väära sisuga, sageli kontrollimatu sensatsiooniline ajakirjanduslik tekst (Ellis 2018: 401; vt ka https://et.wikipedia. org/wiki/Libauudis). Folkloristist jutu-uurijal ilmselt tekib siin, nagu ka WTC turisti foto puhul, assotsiatsioon valetamisnaljandiga, mille esitaja eesmärk 
on kuulajaid/vaatajaid lollitada. Tänapäeva suhtluses võib ühest väga lihtsalt saada teine, näiteks juhuslikult pealtkuuldud ja tõena võetud valetamisnaljandist saab fabritseerida asjatundmatuse tõttu valeuudise (vt Kalmre 2013), kusjuures libauudisele lisatud foto justkui kinnitaks läbi nägemistaju sellesama teksti tõesust. Kui siin välja tuua erisused, siis linnamuistendid võivad ehk rohkem tugineda traditsioonilistele elementidele või süžeeliinidele. Nende kahe üks erisusi (aga ehk ka ühendav aspekt) on see, et valeuudise looja enamasti teab ju, et valetab oma lugejatele ükskõik mis põhjusel, seevastu muistendi rääkija võib lugu nii uskuda kui ka selles kahelda. Kui aga usutavana esitatud valeuudis (isegi kui selles kaheldakse) satub suhtlusringlusesse, muutub see kultuurilise debati osaks ehk muistendiliseks (Ellis 2018: 402; Mould 2018: 414).

Jälgin järgnevalt, kuidas jututeema looduse taastumisest tänu pandeemiale kandus läbi erinevate eelkirjeldatud folkloori ja tänapäeva meedia žanriliste maatriksite, missugune oli selle materjali laiem kontekst ning kuidas see populaarne teema kohandus kohalike kontekstidega ning missuguseid jutumotiive ja strateegiaid kasutati, et tõepära saavutada või seda parodeerida. Ning lõpuks, missugune on selle killukese uudisfolkloori tähendus ja eesmärk.

\section{Uudis delfiinidest Veneetsia kanalites - liiga hea, et olla tõsi}

2020. aastal globaalseks katastroofiks arenenud koroonapandeemia oli omamoodi jätkuks varasematel aegadel, aga 2019. aastal veelgi teravnenud, loodusja kliimakriisile, mille teemadeks olid saastatusest ja soojenemisest tingitud kliimamuutused, suured tulekahjud, metsade, looduse lagastamine, paljude eluslooduse liikide häving ning loomade anomaalne käitumine. Ehk teisisõnu, inimkonna ees seisev küsimus, majanduslik heaolu versus jätkusuutlik looduskeskkond, oli juba enne pandeemia puhkemist maailmas ülimalt aktuaalne. Oli toimunud ka midagi erakordset: mure maailma tuleviku pärast oli jõudnud tänu Rootsi koolitüdrukule Greta Thunbergile ka paljude maailma noorteni, kes korraldasid kliimaproteste kogu maailmas.

Jälgisin koroonakarantiini esimestel kuudel mitmetest uudislugudest alguse saanud meedia ja sotsiaalmeedia jutusuunda, kuidas justkui karantiinist tingitud saaste vähenemine mõjub keskkonnale positiivselt ja loodus taastub. 2020 märtsi lõpus ilmunud fotodega varustatud uudislood Veneetsia kanalite puhtusest ja elurikkuse taastumisest ning luikede ja delfiinide tagasitulekust varem turistide tulva all kannatanud ja nüüd koroonakarantiinis oleva Veneetsia kanalitesse mõjusid igati lootustandvana. Seda enam, et juba mõnda aega oli rahvusvaheline meedia vahendanud artikleid turistide hulgast ja turismi 
kahjulikest tagajärgedest selles ajaloolises linnas. Sellepärast, mis seal salata, ka selle artikli autor uskus ja laikis ühte sarnast FB-s jagatud artiklit. Interneti uudistekanalites arendati sellest mitmeid versioone (Kaur 2020; vt ka BBC News 2020; The Guardian 2020 jpt).

Psühholoogiliselt ja kultuuriliselt on mõistetav ja ajalooliselt jälgitav selliste unistuslike kuulduste ${ }^{5}$ tekitamine ja kiire levik. Kriitilistes olukordades on ühiskonnas olemas niisuguste lugude ootus, nüüd, internetiajastul, on paljudel neist ka tuvastatav motiveeritud autor. Sarnaselt WTC turisti foto algupäraga tegi rahvusvaheline meedia ka selle Veneetsia udujutu algallika üsna pea kindlaks ja lükkas jutu ümber. Lugu luikedest ja delfiinidest oli alguse saanud ühest Twitteri postitusest. Sealt olid selle positiivse uudise üles korjanud mitmed ajakirjanduslikud väljaanded, lisaks sellele kogus see ka miljoneid laike FB-s, Instagramis, TikTokis. Ka Eesti sotsiaalmeedias usuti ja edastati seda siiralt (vt nt Metsallik 2020: Metshaldja päevik jm). Libauudise usutavuse loomisel oli suur tähendus ka seda kinnitavatel fotodel Veneetsia kanalite läbipaistvast veest, kaladest, delfiinidest ning luikedest.

Maailm on võtnud hingetômbepausi.. Vesi Veneetsia kanalites on puhas, õhk on värske, kalad

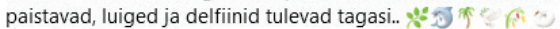

Ja meie siin oleme kodus oma peredega, valmistame oma toidukorrad ise, lapsed koduõppel, väikesed lapsed lasteaedade ja -hoidude asemel kodus oma emade läheduses. Meie loomulik ilu tuleb tagasi, nüüd kui me hoolitseme enda eest ise ega saa sõltuda enam iluteenustest. Me õpime tundma naturaalseid viise enda toetamiseks ja ravima enda keha vitamiinide ja mineraalidega. Me lähme kõik koos sellest läbi, palun hoiame kokku.

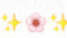

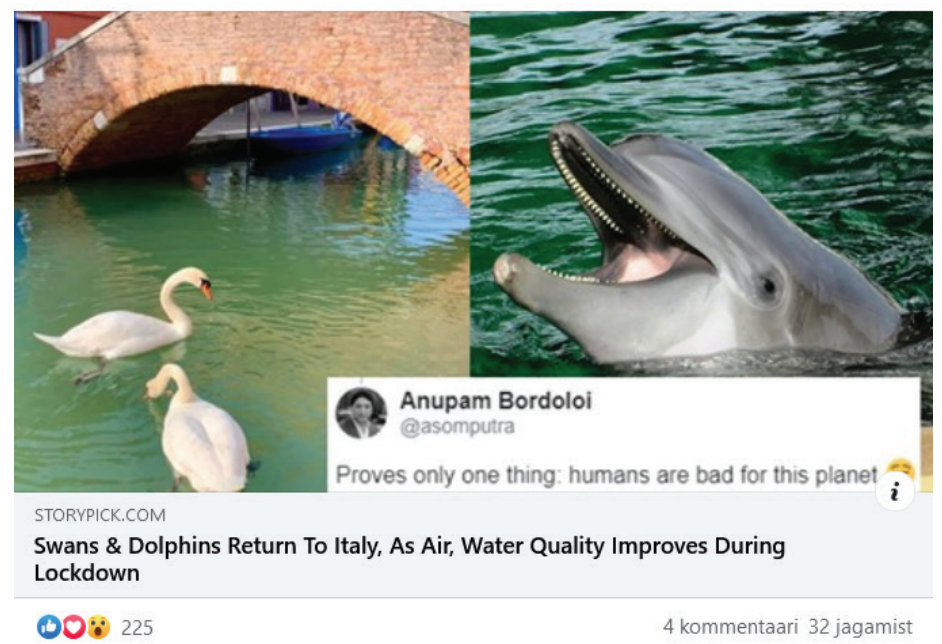

Joonis 1. Metshaldja päevik. Postitus 18. märtsil 2020 (https://www. facebook.com/934357076588456 / posts / 3063094873714655/ - 5.04.2021). Ekraanitõmmis. 
See filmilõik delfiinidest, mida postituses kasutati, oli tehtud Sardiinia sadamas, s.o Vahemeres, sadu kilomeetreid eemal Veneetsiast. Uudise kompileerinud autor ei teadnud, et postitustes olevad luiged ei ole midagi erakordset, nad on sagedased külalised Veneetsia suurlinnapiirkonna väikese saare Burano kanalites, kus fotod olid tehtud. Selguski, et sellel algsel viraalseks läinud pildil oli ka äärmiselt motiveeritud autor, keegi Indias New Delhis elav Kaveri Ganapathy Ahuja, kes väidetavalt nautis oma 16. märtsil Twitteri postitusele ${ }^{6}$ ja pildile osutatud tähelepanu. "Säutsu eesmärk oli lihtsalt jagada midagi, mis pakkus mulle rõõmu nendel süngetel aegadel," ütleb ta. Ta ei eeldanud kunagi, et uudistekanalid selle üles nopivad ja see viraalseks muutub või kahju tekitab (Daly 2020).

\section{Rahvalik meediakriitika}

Kui jälgida rahvusvahelise digiajakirjanduse ja sotsiaalmeedia postitusi, siis uudis Veneetsia puhastumisest ja delfiinide tagasitulekust sinna lükati ümber lausa mõne päevaga, aga enne seda oli uudise levik, ilmselt arvestades globaalset koroonakonteksti, kus elu ja suhtlus toimus peamiselt internetis, olnud plahvatuslik. Nähtavasti just seetõttu, et teema sai nii laialt tuntuks ning vajadus positiivse uudise järele oli nii suur, muutusid seda libauudist parodeerivad meemid sama (aga võib-olla rohkemgi) populaarseteks. Näiteks FB leheküljel Man Page ilmunud meemi haide tulekust põllule järgmise pandeemia ajal kommenteeriti 890 korral ja jagati 57000 korda (vt joonis 2). Ka Eestis
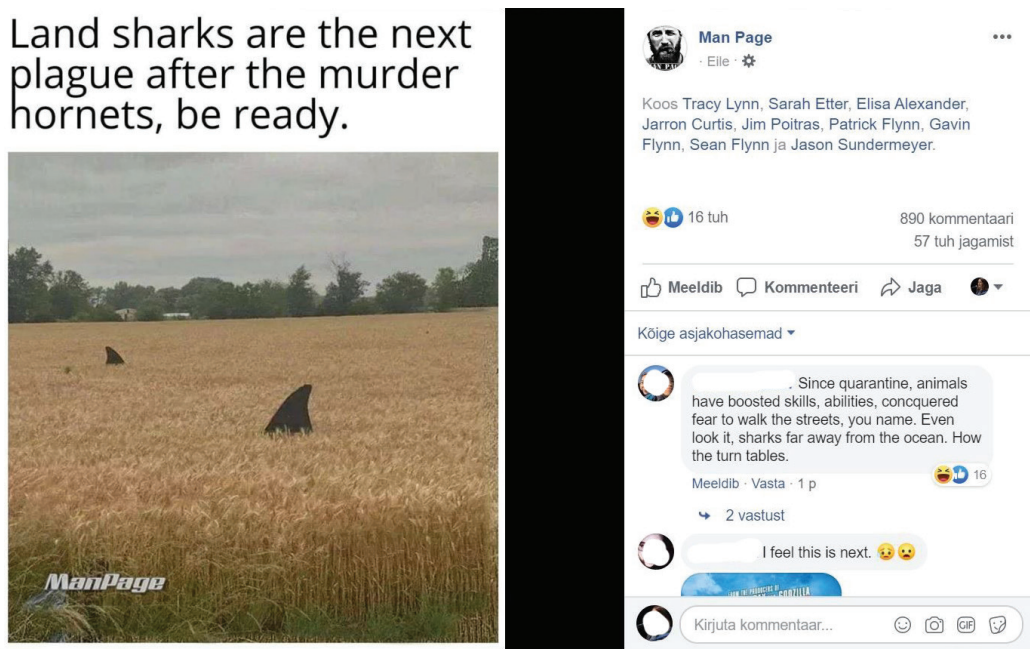

Joonis 2. Man Page. Maismaahaid on järgmine katk pärast tapjaherilasi, ole valmis! Ekraanitõmmis. 
tekkis sellest libauudisest rohkesti parodeerivaid meeme. Kogu selle teema käigusoleku ja leviku ajalist raami kirjeldades tuleb möönda, et uskumiseks mõeldud uudis lükati ümber mõne päevaga. Ahuja tegi oma viraalseks läinud postituse 16. märtsil, juba 20. märtsil kirjutati National Geographicus sellest kui Ahuja meelega tehtud libauudisest (vt Daly 2020) ning minu kogusse laekus Eesti konteksti “tõlgitud” meem delfiinidest Emajões 23. märtsil (joonis 3).

Tutvustan järgnevalt mõningaid iseloomulikumaid meeme neist uudist parodeerivates piltjutustustes. Kuigi neis meemides on esiplaanil sõnum "loodus tuleb tagasi", on iseloomulik, et just kohalikud rahvalikud reageeringud miksivad lokaalsetele reaalsustele tuginevaid taustu ja sümboleid. Valik on väga õnnestunud, sest meil on need olulised looduskohad, mis karantiini ajal taastuma peaksid, Emajõgi ja Taevaskoda. Emajõgi, mida alles hiljuti oli ähvardanud jõe kaldale plaanitava paberivabriku reostus ja üks Eesti pühakohti, Taevaskoda, kus laev Lonni koroonakarantiini ajal enam ei sõida, ja nii on "delfiinid tulnud Taevaskotta jälle paarituma", kusjuures see algupärane lokaalne käsitlus sündis spetsiaalses meemigrupis "Põlva meemid" (joonis 4).

\section{Kaspar Grigorjev}

23. mär kell 12:26 • @

\section{Emajõgi runs clean, dolphins appear in Tartu's waterways amid coronavirus lockdown.}

\section{Vaata tõlget}

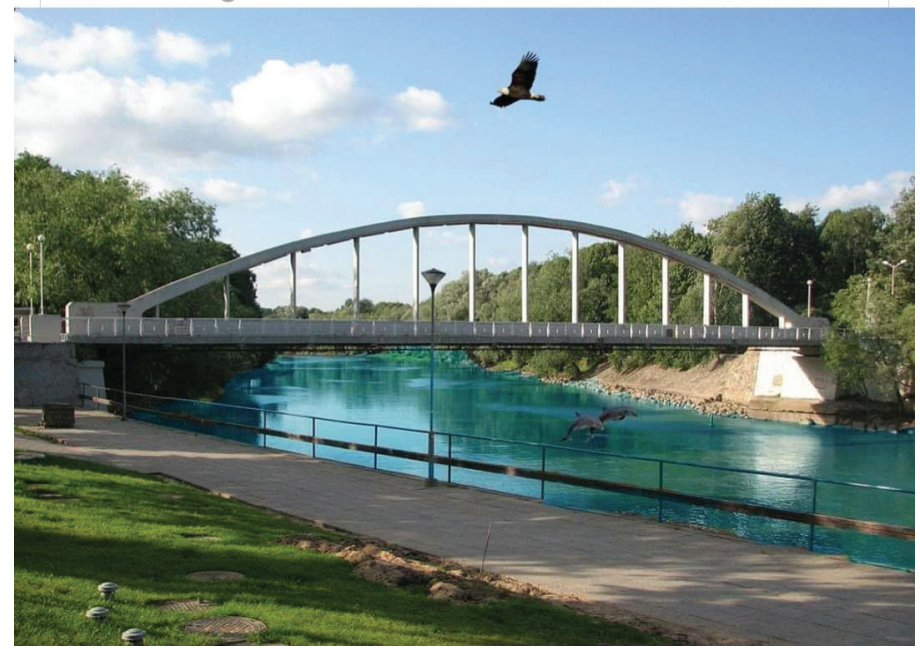

Joonis 3. Emajõgi on nii puhas, et koroonapiirangute ajal on keset Tartut näha delfiine. Facebook, Kaspar Grigorjev 23. märts 2020. Ekraanitõmmis. 

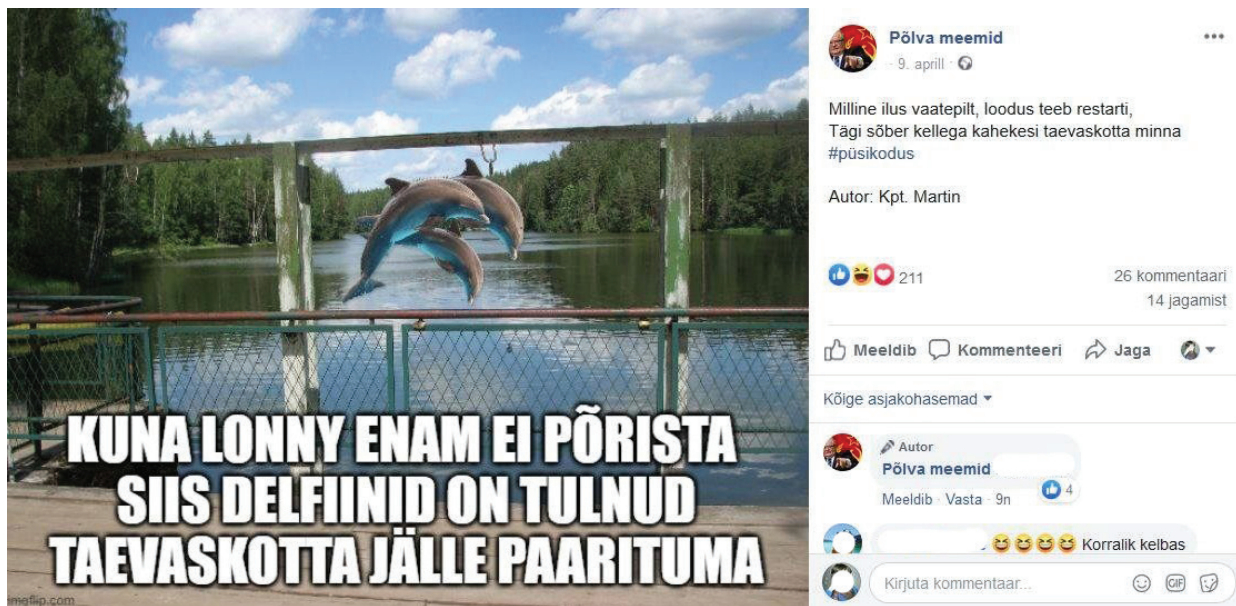

Joonis 4. Põlva meemid. Facebook, 9. aprill 2020. Ekraanitõmmis.

Digitaalne huumori ja satiirileht Abiratas tegi juba 24. märtsil delfiinidest Tartu Emajões koguni väikese pilauudisloo, kus ta asetas selle kohaliku elu konteksti: "tehaste sulgemine jõe ääres on teinud selle vee nii puhtaks, et sinna on naasnud delfiinid, keda pole seal nähtud üle saja aasta..." (abiratas.ee)

Teine osa meeme, kus teemat "loodus tuleb tagasi" tõlgendati mõnevõrra teises võtmes, on seotud kadunud ja väljasurnud loomade naasmisega koroona ajal puhastunud maailma. Näiteks kui inimesed on oma kodudes ja tänavad tühjad, tulevad Šotimaale tagasi kunagi väljasurnud loomad, saurused (joonis 5).

Joonis 5. Kui inimesed varjuvad kodudes ja tänavad jäävad tühjaks, naaseb elusloodus Invernessi, Šotimaa. Ekraanitõmmis.

As people shelter in place and streets remain empty, the wildlife is returning to Inverness, Scotland ...

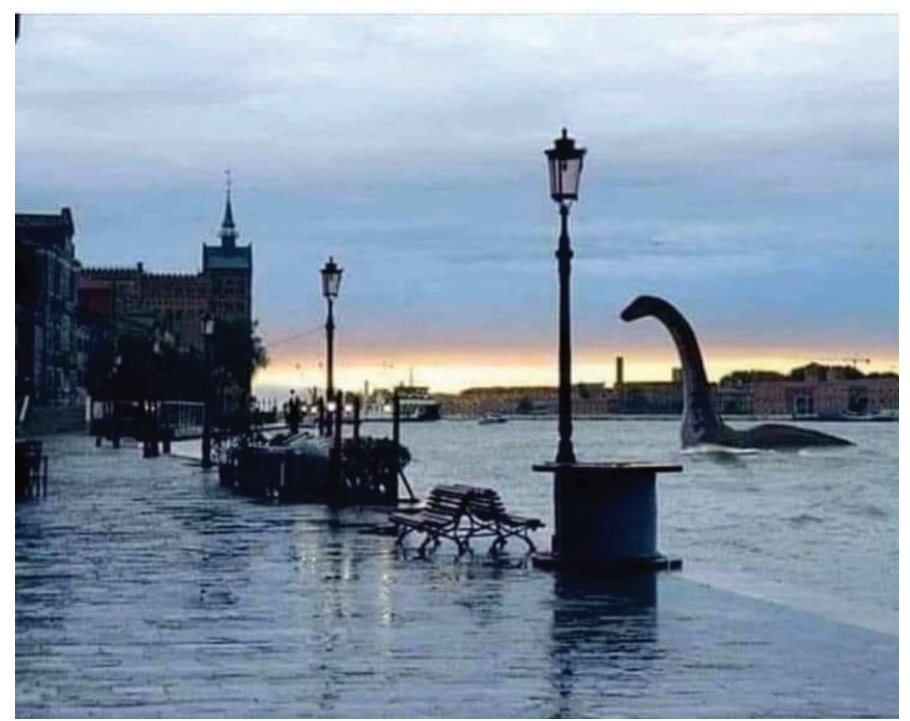


Tegelikult toetasid seda teemat üleilmse pandeemia algusajal paljud enamjaolt märtsi lõpus, libauudise ja meemidega samal ajal, levinud (justkui) reaalsust edasiandvad fotod metsloomadest, kes linnatänavatel uitavad, akna taha tulevad või muidu ebaloomulikult käituvad. Olen mõned näited fotodest talletanud ka oma kogusse, võib ju arvata, et selliste juhtumite tõenäosus oli olemas, aga pandeemia algul levinud fotode hulk lubab siiski arvata, et paljudel juhtudel on tegemist nn valefotodega, kus tegijad on lustinud, kasutades fototöötlust või võltsinud konteksti. Mitmed neist viraalseks saanud loomapiltidest tunnistati üsna kähku meedias ka valeks, nt Twitteris levinud foto purjus elevantidest Yunnani provintsis ${ }^{7}$ (vt ka Daly 2020). Eestis oli üks populaarsemaid libafotosid ülesvõte akna taga piiluvast karust, kes tunneb huvi, kuhu need inimesed siis jäänud on (joonis 6).

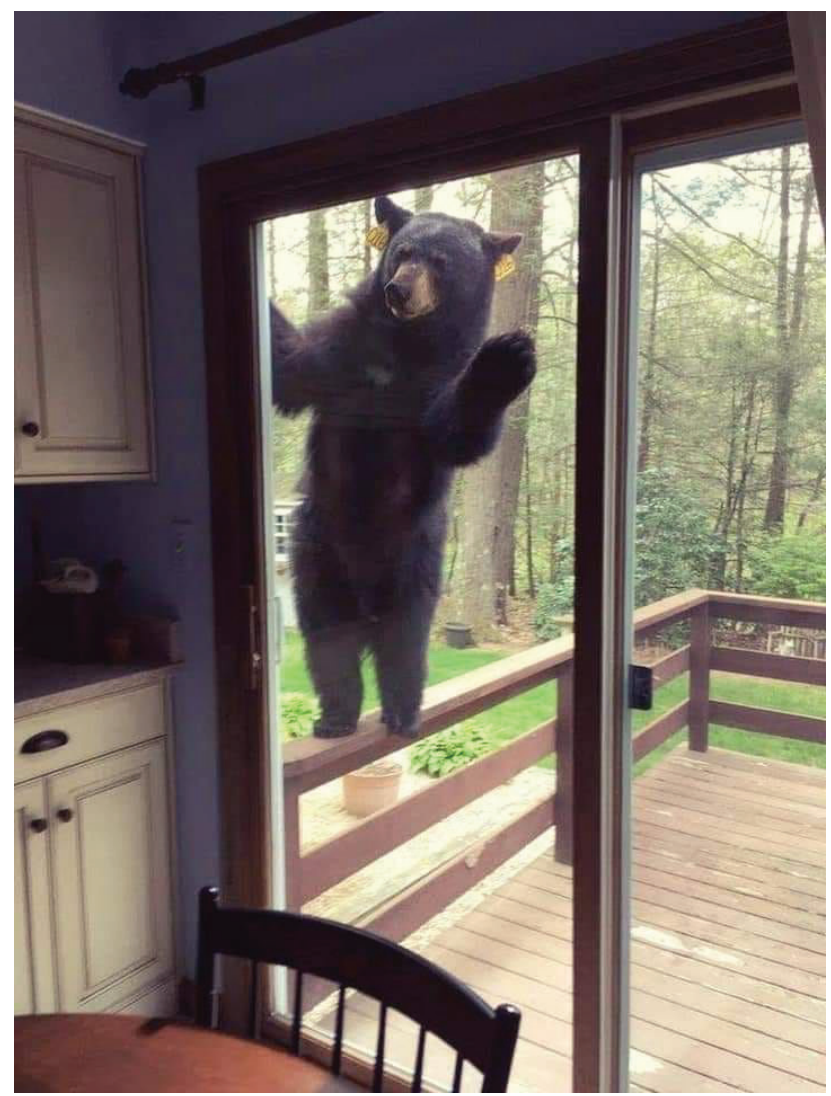

Joonis 6. Pilt eri keeltes levinud meemist "Mitu nädalat pole väljas käinud. Loomad tulevad kontrollima, kas kõik on korras". Ekraanitõmmis. 
Üks konkreetne juhtum Eestis kinnitas loomade anomaalset käitumist ja tõestas justkui üldisi arvamusi selles vallas. Nimelt leidis Tallinnas 14. ja 15. mail aset vahejuhtum linna eksinud kahe karuga, keda püüti ja kelle eest inimesi hoiatati. Juhtum tekitas palju elevust, koos uudislugudega levis igasugust pärimust: keelenalju, meeme jm. Piret Voolaid on kirjutanud Sirbis Tallinna karusaaga kajastumisest sotsiaalmeedias ja niisuguse materjaliloome intertekstuaalsusest olemusest: "Varasemaid kultuuritekste modifitseerides toetuvad internetikasutajad jagatud glokaalsele ${ }^{8}$ kultuuripagasile ja tekstiressurssidele kogukonna (siinsel juhul eestlaste) kollektiivses mälus. Kohandatavate motiivide allikaks saavad nii suuline pärimuskultuur kui ka tüvitekstid, mis on omandatud nt koolilugemuse, kohustusliku kirjanduse, aga ka muusika (laulusõnad), kunsti, filmide, reklaami ja massimeedia vahendusel" (Voolaid 2020).

Kolmandas selle valdkonna meemikategoorias laiendatakse teemat "maailm puhastub ja loodus tuleb tagasi" sellega, et peale taastuva looduse naaseb ka ajalugu. Nt tänu karantiinile on Põhjameri saanud nii puhtaks, et sinna on tagasi tulnud viikingid (joonis 7); tänu koroonakarantiinile puhastuvad Valgevene metsad ja sinna tulevad tagasi partisanid (joonis 8); ja kui delfiinid tulevad Itaaliasse, siis Venemaale naasevad Lenin ja Stalin (joonis 9).

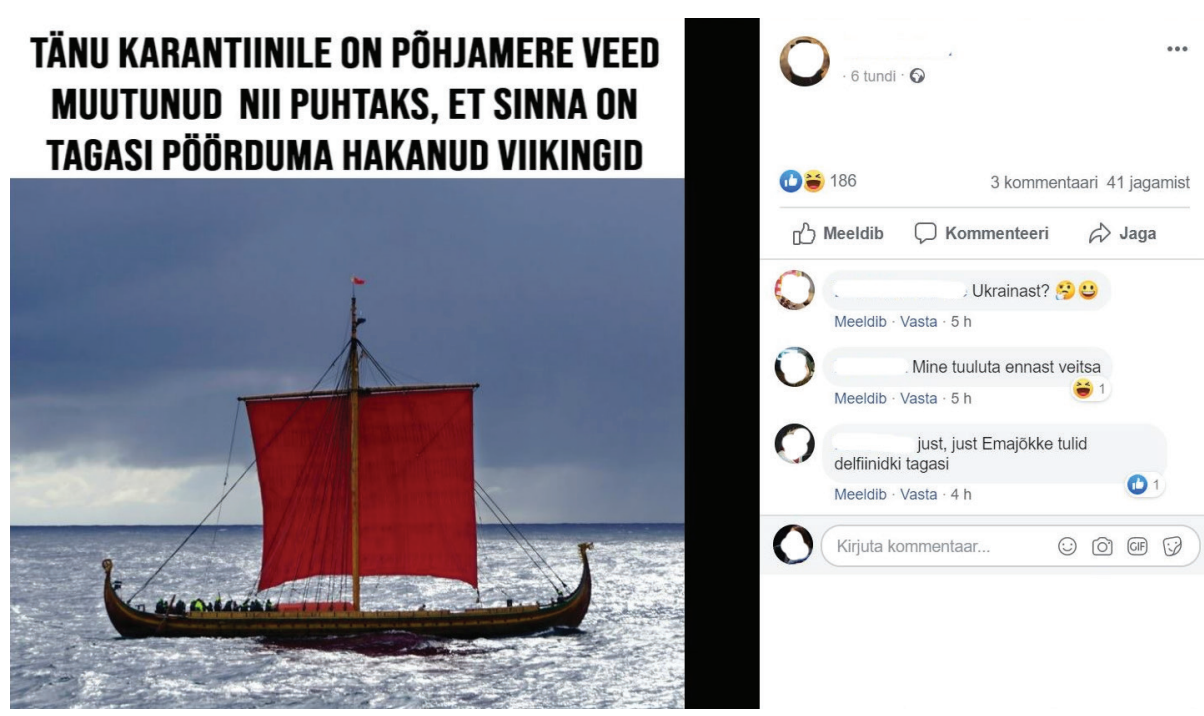

Joonis 7. Viikingite naasmise meem. Ekraanitõmmis. 


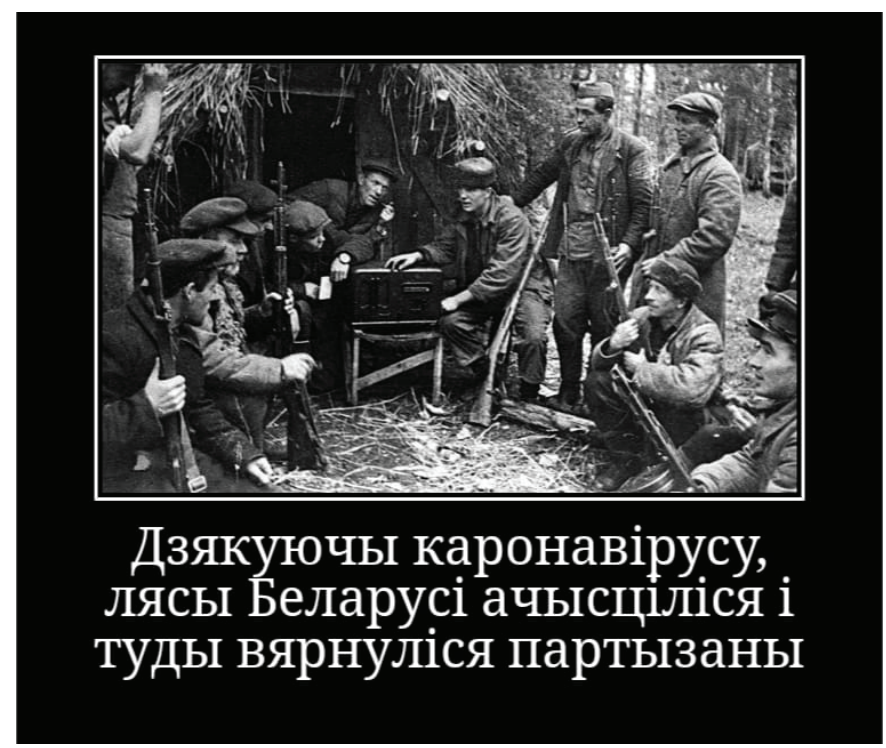

Joonis 8. “Tänu koroonaviirusele paranevad Valgevene metsad ja sinna on naasnud partisanid”. Ekraanitõmmis.
(6)
Babushka
9 Apr at 17:02 • 9

\section{Dolphins have returned to italy}

\section{Rusia :}

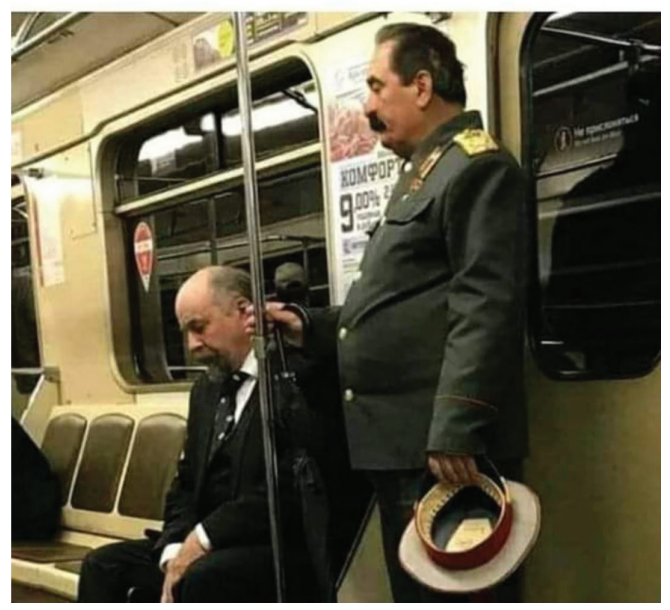

Joonis 9. "Delfiinid on naasnud Itaaliasse. Venemaal:" Postitatud 9. aprillil 2020. Ekraanitõmmis. 


\section{Kokkuvõtteks}

Eelpool käsitletud ühe teema diakrooniline areng libauudisest sellesama tõena pakutud uudise rahvalikuks kriitikaks, mille tavapäraseks väljenduseks on meemid, on tänapäeva osaluskultuurilises meedias üsna tavapärane tee. Niisugusele nähtusele on iseloomulik lühiajalisus, kiire tõus ja hääbumine. Tegelikult võib konstateerida, et siin käsitletud libauudise ja meemide tekkest kuni allakäigu ja kadumiseni kulus vaevalt paar nädalat.

Selle teema puhul on hästi jälgitav kuidas pildilisus, mis libauudise puhul oli osa tõe retoorikast, sest tekstilise osa juures on ka seda sündmust kirjeldav foto, pöördus nüüd sellesama tõe rahvalikuks kriitikaks. Diane Goldstein on märkinud, et meemid tähistavad justkui intertekstuaalset sidet vale ja rumalusega. Kusjuures diskursiivsete strateegiatena on varasemate tekstide, illustratsioonide ja fotode laenamine väga iseloomulik, et seda libauudiste ebatõde ja ignorantsust ning küündimatust esile tuua (Goldstein 2018: 474).

Siin esitatud materjali puhul ei jää tänapäeva muistendi uurijal märkamata ka nende meemide e viraalselt levivate piltjutustuste puhul kasutamist leidnud muistendimotiivid. Üks niisugune uskumuslik jutumotiiv on väljasurnud loomade või ka lumeinimese salajasest olemasolust tänapäeva maailmas, Šotimaa järves elavast eelajaloolisest Loch Nessist. Teine äratuntav jutumotiiv, mida ka selle teema puhul parodeerivas võtmes kasutati, põhineb uskumusel, et kangelased (siin Lenin, Stalin, ka partisanid või viikingid) ei ole surnud, vaid eksiteerivad kuskil, et sobivatel asjaoludel end uuesti ilmutada. Ehkki nende uskumuste juuri võib leida vanemast pärimusest, on kujutelmad väljasurnud isendite, loomade (dinosauruste jt) salajasest olemasolust ilmselt võimendunud tänu fantaasiakirjandusele ja filmidele. Popkultuuri mõjutustega on ka motiiv kangelaste salajasest elust. Kolmas modernne muistendipärane teema neis meemides ja libafotodes on selle põhiline sõnum - oma keskkonnast väljunud ja inimesi ohustavad metsloomad või anomaalselt käituvad loomad, linnud: karud, tapjamesilased/vapsikud, haid, delfiinid (vt ka Campion-Vincent 2004; Meder 2007 jt).

Korduva mustriga loomisprotsess internetimeedias - väga sarnane varasema suulise jutuloomega - on mingit moodi ohtlike või antud kontekstis eriliste loomade fototöötluslik lisamine ning selle abil mingist erilisest või ohtlikust olukorrast jutustava uue valefoto loomine. Üks hea näide on sellest, kuidas on internetis toimetatud fotograaf Thomas Peschaki üle kümne aasta tagasi Lõuna-Aafrikas tehtud fotodega valgest haist. Selle Peschaki tehtud fotolt kopeeritud ohtliku mereelukaga on internetis loodud ja ringlema lastud fotojutustusi sama hai kohalolust orkaanist üleujutatud linnades, sellest kuidas ohtlik elukas jälitab merel pahaaimamatut meest väikeses paadis jms (vt Keefe 2018). 
Haid (mitte ainult fotograaf Pescaki pildistanuna) ja alligaatorid/krokodillid on populaarsed tegelased paljude internetis ringlevate libafotode stseenides, nad kujutavad veest lähtuvat salajast ohtu ka näiteks orkaanidest üleujutatud linnade piltidel (vt nt Frank 2003: 126 jj).

Huumor on kriisikäitumise oluline osa, tänapäeval saavad internetikasutajad neid meeme jagades selles protsessis osaleda. Meemide abil vahendatud meediakriitika toob huumorivõtmes esile ka tegelikke aktuaalseid teemasid. Käesoleval juhtumil tõusis esile üha rohkem aktualiseeruv mure maailma tuleviku pärast, looduskeskkonna ja eluslooduse pärast. Folkloristid kindlasti ei juurdle, kas meeme on tark levitada, nad jätavad selle teema pigem sotsiaal-, psühholoogia-, meedia-, poliitika- jt teadlaste (h)arutada, sest üldise arusaama kohaselt annavad just libauudised valesid lootusi, nende levitamist on vaja kontrollida ning tõde välja selgitada. Tavaajakirjanduses püütakse seda ka teha, näiteks sellegi teema puhul internetiväljaandeid üheteistkümne kuu pärast üle vaadates selgus, et mõnel juhul olid neist delfiinid ja luiged välja redigeeritud, piirdutud ainuüksi väitega Veneetsia kanalite puhtamaks minemisest (vt nt The Guardian).

Sellel libauudisel, fotoshopitud linnamuistendil või kuuldusel oli globaalne levik, aga ta "tõlgiti" väga kergesti ka kohalikku konteksti. Pandeemia ajal kogutud materjali iseloomustab täies ulatuses asjaolu, et miksitud on tõeseid ja fabritseeritud tekste, fotosid, videoid. Nii nagu kuulujutud ja linnamuistendidki peegeldavad siin käsitletud pildijutud inimeste latentseid unistusi paremast, vabamast, puhtamast ja turvalisemast maailmast. See on uskumuste ja linnamuistendite üks seni vähem avatud funktsioone. ${ }^{9}$

Folkloristlikust vaatepunktist on need libauudise vormis algselt valetamisnaljandi funktsioonis esitatud ja edaspidi muistendite libiseva tõeskaalaga kuuldused üks osa toimetuleku strateegiatest, nn kriisihuumor, aga samas ka positiivset kujutelma edastav uskumusjutt, mis suuresti apokalüptiliselt tajutud pandeemia-aega ümbritseb ja inimeksistentsi laiemalt mõtestab. Isegi kui neil libauudistel ja hiljem tekkinud meemidel ei ole tõeväärtust, annavad nad edasi ideed - loodus taastub - ning pakuvad kindlasti lootust ja heaolutunnet. Idee, et loomad ja loodus võiksid selle kriisi ajal tegelikult õitseda, "võiks anda meile mõtte ja eesmärgi - et me läbisime selle kriisi põhjusega" (Daly 2020).

\section{Tänusõnad}

Kirjutis on seotud Eesti Kirjandusmuuseumi uurimisprojektiga EKM 8-2/20/3 "Folkloori narratiivsed ja uskumuslikud aspektid" ja EKKD65 "Kuidas allikatest saab kultuur: eesti aines Eesti Kirjandusmuuseumi kogudes ja andmebaasides”, 
selle valmimist toetas Euroopa Liit Euroopa Regionaalarengu Fondi kaudu (Eesti-uuringute Tippkeskus, TK 145).

\section{Kommentaarid}

1 Üks suuremaid rahvusvahelisi projekte on "Humor during the global Corona Crisis". Koostööprojekti juhtpartnerid on Giselinde Kuipers (Leuveni Katoliiklik Ülikool) ja Mark Boukes (Amsterdami Ülikool), projekti on kaasatud rohkem kui 30 riigi teadlased, sh Eesti teadlased. Eri keeltesse tõlgitud küsitluskava (https://edu.nl/kp8xe) kaudu paluti inimestel saata internetikasutajate hulgas levivaid nalju, sh meeme. Globaalne kogu on võrdlevate uuringute eesmärgil kättesaadav kõigile projekti osapooltele (Kõiva \& Voolaid 2020: 183).

2 Mõiste 'meem' võttis kasutusele Richard Dawkins, et kirjeldada väikesi geenidega sarnanevaid kultuurilise muundamise üksusi (Dawkins 1976). Viimasel ajal on neist internetisuhtluses saanud rahvaliku eneseväljenduse oluline osa.

3 Tollane sõnavõtt ja arutelu toimus kõigi kvoorumil osalejate vahel konverentsi lõpus. (Autori kommentaar.)

4 Muistendite ja huumori suhet on kirjeldanud ka Bill Ellis (2005).

5 Donald Allport ja Leo Postman nimetasid selliseid Teise maailmasõja ajal levinud ootuspäraseid kuulujutte unistuslikeks e udusteks (dream or foggy) kuuldusteks (Allport \& Postman 1947). Üks niisuguseid oli näiteks kuuldus Stalini surmast, mis oleks koletu sõja lõpetanud.

6 Paraku ei ole originaalne postitus aprillis 2021 enam kättesaadav.

7 Vthttps://twitter.com/Spilling_The_T/status/1240387988682571776?s=20 (vaadatud 30.03.2021).

8 "Mitme sündmuse ja selle järgse folkloorilainetuse hübriidsust saab vaadelda ka glokaliseerumisena. Sõnadest globaliseerumine ja lokaliseerimine moodustatud kohversõna glokaliseerumine tõi kasutusele Ameerika sotsioloog Roland Robertson 1990. aastate lõpus ja see tähendab üleilmsete ja kohalike ühiskondlike, poliitiliste ja majanduslike nähtuste üheaegset esinemist" (Voolaid 2020).

9 Käesoleva artikli autor on linnamuistendi "Madu päästab poisi" puhul toonud välja nende uskumusjuttude imedele ja lootustele rajaneva külje: kõik on võimalik ja kõik võib muutuda paremaks (Kalmre 2018: 35).

\section{Kirjandus}

abiratas.ee $=$ Viiruse positiivne pool: karantiinist tingitud saaste vähenemine on toonud Emajõkke tagasi delfiinid. abiratas.ee 24.03.2020 (https://abiratas.ee/viiruse-positiivnepool-karantiinist-tingitud-saaste-vahenemine-on-toonud-emajokke-tagasi-delfiinid/ 30. märts 2021).

Allport, Donald \& Postman, Leo 1947. The Psychology of Rumor. New York: Henry Holt and Company. 
BBC News 2020 = Coronavirus: Venice canals clearer after lockdown. BBC News. Europe 18. märts (https://www.bbc.com/news/av/world-europe-51943104/coronavirus-venicecanals-clearer-after-lockdown - 31. märts 2021).

Bennett, Gillian 1988. Legend: Performance and Truth. Bennet, Gillian \& Smith, Paul (toim). Monsters with Iron Teath. Perspectives on Contemporary Legend, vol III. Sheffield: Sheffield Academic Press, lk 13-36.

Campion-Vincent, Véronique 2004. Ühiskonna vastukajad huntide Prantsusmaale taasilmumisele. Katse analüüsida kuulujuttude tõe pähe võtmist. Mäetagused 24, lk 219-264 (doi: 10.7592/MT2003.24.hundijutt).

Daly, Natasha 2020. Fake animal news abounds on social meedia as coronavirus upends life. Bogus stories of wild animals flourishing in quarantined cities gives false hope - and viral fame. National Geographic, 20. märts (https://api. nationalgeographic.com/distribution/public/amp/animals/2020/03/coronaviruspandemic-fake-animal-viral-social-media-posts?fbclid=IwAR2o_B4Z6_ d7mpschqhRzkG8tKqL4DPzCET3CDeMzttQyVLwvxqrLzeG5-E - 31. märts 2021).

Dawkins, Richard 1976. The Selfish Gene. Oxford: Oxford University Press.

Ellis, Bill 2005. Humour as an Integral part of the Contemporary Legend Process. Fine, Gary Alan \& Campion-Vincent, Véronique \& Heath, Chip (toim). Rumor Mills. The Social impact of Rumor and Legend. New Brunswik \& London: Aldine Transaction, lk 123-140.

Ellis, Bill 2018. "Fake News" in the Contemporary Legend Dynamic. Journal of American Folklore 131 (522), lk 398-404 (doi: 10.5406/jamerfolk.131.522.0398).

Frank, Russell 2003. 'Worth a thousand words': The photographic urban legend and the illustrated urban legend. Contemporary Legend 6. New Series, lk 119-145.

Frank, Russell 2011. Newslore: Contemporary Folklore on the Internet. Jackson: University Press of Mississippi.

Goldstein, Diane 2018. Never Remember: Fake News Turning Point and Vernacular Chritiques of Bad Faith Communication. Journal of American Folklore 131 (522), lk 471481 (doi: 10.5406/jamerfolk.131.522.0471).

Hiiemäe, Reet \& Kalda, Mare \& Kõiva, Mare \& Voolaid, Piret 2020. Koroonakriisi rahvapärased väljendused Eestis. Keel ja Kirjandus 12, lk 1011-1032.

Kalmre, Eda 2013. On Reality, Truth and Ideologies in the Case of Munchausen Tales. Folklore. Electronic Journal of Folklore 53, lk 141-158 (doi:10.7592/FEJF2013.53. kalmre).

Kalmre, Eda 2018. Legends about the Afganistan War: The Boy Saved by the Snake. What a Wonderful World of Legends. Articles on rumours and legends. Tartu: ELM Scholarly Press, lk 23-37.

Kaur, Loveleen 2020. Swans \& Dolphins Return to Italy, As Air, Water Quality Improves During Lockdown, 17. märts (https://www.storypick.com/water-and-air-quality-improvein-italy/ - 31. märts 2021). 
Keefe, Alexa 2018. How the ultimate shark photo went viral. National Geographic, 8. november (https://www.nationalgeographic.com/animals/article/great-white-sharkmeme-news-photography-animals-peschak - 31. märts 2021).

Kõiva, Mare \& Voolaid, Piret 2020. Kriisiaegne koroonapärimus Eesti Kirjandusmuuseumi folkloristika osakonna teadlaste huvisfääris. Mäetagused 77, lk 177-185 (http:// www.folklore.ee/tagused/nr77/u01.pdf - 31. märts 2021).

Meder, Theo 2007. The Hunt for Winnie the Puma: Wild Animals in a Civilized Dutch Environment. Contemporary Legend 10, lk 95-127.

Metsallik, Mari 2020. Metshaldja päevik 18. märts. Facebook (https://www.facebook. com/934357076588456/posts/3063094873714655/ - 5. aprill 2021).

Mould, Tom 2018a. A Doubt-Centered Approach to Contemporary Legend and Fake News. Journal of American Folklore 131 (522), lk 413-420 (doi: 10.5406/jamerfolk.131.522.0413).

Shifman, Limor 2007. Humour in the Age of Digital Reproduction: Continuity and Change in the Internet-Based Comic Texts. International Journal of Communication 1, lk 187-209 (https://ijoc.org/index.php/ijoc/article/viewFile/11/34 -31. märts 2021).

Shifman, Limor 2011. An Anatomy of a YouTube Meme. New Media and Society 14 (2), lk 187-203 (doi: 10.1177/1461444811412160).

Shifman, Limor 2014. The Cultural Logic of Photo-Based Meme Genres. Journal of Visual Culture, detsember (doi: 10.1177/1470412914546577).

Tatrik, Esta 2020. Esta Tatrik: Hiina juuksenõel. Postimees, 18. aprill (https://leht. postimees.ee/6951533/esta-tatrik-hiina-juuksenoel - 31. märts 2021).

The Guardian 2020 = 'Nature is taking back Venice': wildlife returns to tourist-free City. The Guardian, 20. märts (https://www.theguardian.com/environment/2020/mar/20/ nature-is-taking-back-venice-wildlife-returns-to-tourist-free-city - 31. märts 2021).

Voolaid, Piret 2020. Püsi kodus, karu tuleb! Ehk Millest jutustab Haabersti karujahiga seotud glokaalne folkloorilainetus? Sirp, 29. mai (https://sirp.ee/s1-artiklid/c21teadus/pusi-kodus-karu-tuleb-ehk-millest-jutustab-haabersti-karujahiga-seotudglokaalne-folkloorilainetus/?fbclid=IwAR2YLgVUuW9suifSAIhTXt6WU5bio33Khu czTas1oaeRa5fIKt24JIg4W0g - 31. märts 2021).

\section{Summary}

\section{Nature is coming back: Dolphins and dinosaurs. About fake news, photoshop-legends and memes during corona quarantine}

\section{Eda Kalmre}

Senior Research Fellow

Department of Folkloristics, Estonian Literary Museum

eda.kalmre@folklore.ee 
Keywords: contemporary legend, fake news, meme, parody, participatory culture, rumour, social media, tall tale

The article follows the narrative trend initiated by the social media posts and fake news during the first months of the corona quarantine, which claims that the decrease of contamination due to the quarantine has a positive effect on the environment and nature recovery. The author describes the context of the topic and follows the changes in the rhetoric through different genres, discussing the ways in which a picture can tell a truthful story. What is the relation between the context, truth, and rhetoric?

This material spread globally, yet it was also readily "translated" into the Estonian context, and - what is very characteristic of the entire pandemic material - when approaching this material, truthful and fabricated texts, photos, and videos were combined.

From the folkloristic point of view, these rumours in the form of fake news, first presented in the function of a tall tale and further following the sliding truth scale of legends, constitute a part of coping strategies, so-called crisis humour, yet, on the other hand, also a belief story presenting positive imagery, which surrounds the mainly apocalyptically perceived pandemic period and interprets the human existence on a wider scale. Even if these fake news and memes have no truth value, they communicate an idea - nature recovers - and definitely offer hope and a feeling of well-being.

Eda Kalmre $(\mathrm{PhD})$ on Eesti Kirjandusmuuseumi folkloristika osakonna vanemteadur. Tema uurimisvaldkonnaks on olnud tänapäeva folkloori ilmingud ja tunnusjooned ning rahvajuttude sotsiaalne ja ajalooline aspekt. Kalmre paljude artiklite ja monograafiate fookuses on olnud tänapäeva muistendid ja kuulujutud ning nende läbi levivad ideed ja praktikad, nendel põhinevad kommunikatsioonivormid tänapäeva meedias. Eda Kalmre on kirjutanud artikleid, koostanud ja toimetanud ajakirjade erinumbreid ning on monograafiate "The Human Sausage Factory. A Study of Post-War Rumour in Tartu" (Rodopi 2013) ja "What a Wonderful World of Legends! Articles on Rumours and Legends" (ELM Scholary Press 2018) autor.

Eda Kalmre $(\mathrm{PhD})$ is Senior Research Fellow $(\mathrm{PhD})$ at the Department of Folkloristics of the Estonian Literary Museum, Estonia. Her main fields of interest are manifestations and features of contemporary folklore and the social and historical aspects of folktales. Kalmre's numerous articles and monographs focus on contemporary legends and rumours with their ideas and practices, and the communication forms based on them in contemporary media. Kalmre has also compiled and edited special issues of journals and has authored monographs titled The Human Sausage Factory. A Study of Post-War Rumour in Tartu (Rodopi 2013), and What a Wonderful World of Legends! Articles on Rumours and Legends (ELM Scholarly Press 2018).

eda.kalmre@folklore.ee 